\title{
Industry 4.0 concept as an incentive to increase the competitiveness of the food and processing industries of the Russian Federation
}

\author{
Vladimir Filatov ${ }^{1 *}$, Victor Mishakov ${ }^{2}$, Svetlana Osipenko ${ }^{3}$, Svetlana Artemyeva ${ }^{4}$, and Irina \\ Kolontaevskaya ${ }^{5}$
}

${ }^{1}$ Moscow State University of food production, Volokolamsk highway St., 11, 125080 Moscow, Russia

${ }^{2}$ The Kosygin State University of Russia, (Technology. Design. Art), Sadovnicheskaya St., 33/1, 117997, Moscow, Russia

${ }^{3}$ Military University of the Ministry of Defense of the Russian Federation, B. Sadovaya St., 14, 123001, Moscow, Russia

${ }^{4}$ K.G. Razumovsky Moscow State University of Technologies and Management (the First Cossack University), Zemlyanoy Val St., 73, 109004 Moscow, Russia

${ }^{5}$ Moscow Witte University, 2-nd Kozhukhovsky proezd St., 12/1, 115432, Moscow, Russia

\begin{abstract}
This work is devoted to the analysis of "Industry 4.0" concepts as an incentive to increase the competitiveness of the food and processing industry of the Russian Federation. The article explores the phenomenon of the fourth industrial revolution as a modern stage of scientific, technical and technological progress. The upcoming fourth industrial revolution is a serious challenge for the government. The main competition of the new revolution is not so much in the technologies themselves but in the skills and education that are necessary for their use. Competition is escalating at the level of education systems but ready-made specialists in the context of globalization still need to be kept, and nowadays the low level of salaries in Russia contributes to a further brain drain. Finally, in the development of Industry 4.0 a systematic approach is important taking into account national characteristics but today it is not in Russia. The development of individual elements of the new industrial revolution is unstable that is why the additional advantages of interdisciplinary research and development are missed. A new round in the development of production will greatly change the social landscape. In order to prevent fatal mass technological unemployment it is necessary to create a social ecosystem for the smooth introduction of technologies with their social design. It is shown that it is accompanied by increased integration, concentration of economic assets under the control of larger business entities. In this regard, the possible consequences of the Fourth Industrial Revolution in the social and humanitarian sphere are examined, and the problem is also raised regarding the development of the Russian food and processing industry of the Russian Federation.
\end{abstract}

\footnotetext{
${ }^{*}$ Corresponding author: filatov_vl@mail.ru
} 


\section{Introduction}

Since 2010 there has been an increase in the number of dissertations and scientific publications devoted to the development of "Industry 4.0" concept as an incentive to increase the competitiveness of the food and processing industry of the Russian Federation. The main surge of interest in this problem was noted in studies of Russian and foreign scientists in 2015-2017 (Y.A. Sukhodolov [1], Frey C. B., Osborne M.A.[2], Manyika J. [3]). In addition, many Russian scientists investigated the impact of the Industry 4.0 Concept on improving the competitiveness of the food and processing industries of the Russian Federation (E.I. Pavlova, A.V.Kozlov [4]). At the same time, the digitalization of Russian industry is developing so rapidly that it is necessary to constantly update research results to take into account all new factors and trends that affect the competitiveness of the food and processing industries of the Russian Federation (I.M. Rukina, V.V. Filatov [5]).

Industry 4.0 concept of was formulated in 2011 by the President of the World Economic Forum in Davos, Klaus Schwab. Industry 4.0 is not a new technology but a completely new approach to production. Its essence lies in the convergence of the three worlds namely technological (material), digital (virtual) and biological. Activities in Industry 4.0 release the huge potential of a person's creative power, actualizes his ability to transform himself, society and the environment [6].

Industry 4.0 got its name in 2011 as a result of the initiative of German businessmen and scientists who defined it like this: "a means of increasing the competitiveness of the manufacturing industry in Germany through enhanced integration of cyberphysical systems, or CPS in factory processes." The USA followed the example of Germany and the companies General Electric, AT\&T, Cisco, IBM and Intel created the Industrial Internet Consortium in 2014. A similar initiative exists in China. In Russia at the end of August 2015 Russian Space Systems and Rostelecom signed a memorandum on creating the Association for the Promotion of Industrial Internet Development.

\section{Materials and Methods}

The methodological basis of this study was the scientific research of Russian and foreign researchers involved in the study of "Industry 4.0" Concept and its impact on the development of various industries.

To conduct this study the authors of the article used theoretical and empirical methods, the method of consolidation and generalization of the research results, methods of expert assessment and a comprehensive analysis of problems, the method of preference vectors.

The methodological base in the study of "Industry 4.0" Concept and its impact on the development of various industries were the works of foreign authors such as (Ghobakhloo M., 2018 [7]), (Lee K., 2020 [8]), (Y. Yin, 2018 [9]), (G.R.K. Reddy, 2016 [10] ), (S.S. Nosova, 2018 [11]), (Dzobelova V., 2020 [12]), (M. Ragnedda, GW Muschert., 2015 [13]), as well as the work of Russian researchers, in particular changes in the nature of labor and labor relations under the influence of the Fourth Industrial Revolution (Balashova E., 2018 [14] ), (Dravitsa V., 2016 [15]), (Lopez Y.I.P., 2019 [16]), (Kazmina I., 2020 [17] ), and others.

\section{Results and discussion}

Digital-transformation in our understanding is a way of adapting to rapidly changing conditions and ultimately a way of survival in the competition. The steel markets in which food and processing enterprises operate are very competitive. The unresolved problem of 
capacity utilization aggravates the situation which creates constant "tension" in the industry: manufacturers fight daily for each client, for a fraction of a percent in the prime cost [18].

Today the density of robotics in Russia is 70 times lower than the global average, according to the National Association of Robotics Market Participants (hereinafter referred to as NARMP). The average annual sales of industrial robots in Russia are 600 items; an average of 240,000 items in the world. In Russia in 2017 there were about 8,000 of these robots; and in the world more than 1.5 million. According to forecasts by NARMP the average annual growth in sales of industrial robots in 2005-2015 is amounted to $27 \%$. From 2016 to 2020 it will be about 50\%, they predict in NARMP, (Fig. 1). According to the calculations of the Ministry of Industry and Trade of Russia, by means of robotics and improved automation they increase labor productivity in the Russian economy by $30 \%$ by 2025 , and by $95 \%$ by 2035 [19] .

Vitaly Nedelsky, president of the National Association of Robotics Market Participants (NARMP), believes that the Russian robotics market is underdeveloped because Russia buys few industrial robots and has virtually no own production. They are poorly demanded in Russian industry, and there are a number of reasons for this [20]:

1) Weak awareness of technical management.

2) Difficulties of industrial adaptation (the need to rebuild work processes).

3) Some of the large enterprises are in state ownership; this gives a lot of inertia.

4) There are few technologically advanced industrial enterprises in Russia.

5) Low labor costs, which makes the robot less cost-effective.

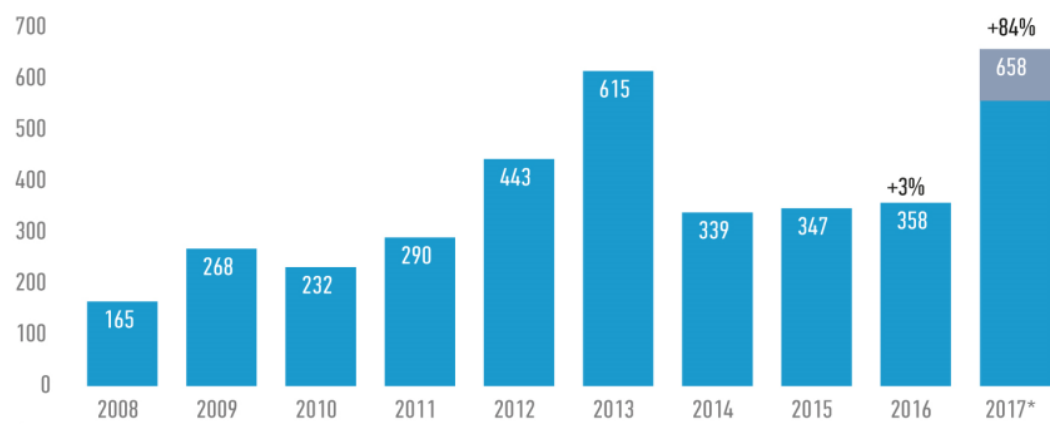

Fig. 1. Average annual sales growth of industrial robots in the Russian Federation

Of course, sooner or later Russia will come to robotization, and there are economic reasons for this: labor is becoming more expensive; robotics is cheaper, and young people are leaving the industrial sector. According to the forecasts of the IFR agency, by 2019 the number of industrial robots used will increase from about 1.5 million in 2015 to more than 2.5 million. In terms of robot density, Korea ranks first namely 531 multi-functional robots for 10 thousand workers involved in industry. In Russia there is only 1 robot per 10 thousand employees. NARMP President Vitaly Nedelsky noted that our country is still 7-10 years behind in robotics [21].

Many experts note the following difficulties in the development of industrial digitalization in Russia:

1) The gap between potential and commercialization. Domestic production does not cover the needs of the great potential of the Russian robotics market.

2) Lack of highly qualified personnel and engineering schools. In general, the quality and quantity of graduated robotics specialists corresponds to weak demand.

But the situation has some positive aspects. There is a well-known saying: "Where there is no competition, we sleep better but live worse." Competition is one of the necessary 
conditions for the development of a market economy; it forces companies to leave the comfort zone and constantly look for new growth points. The possibilities of Industry 4.0 can become a point of growth for the food and processing industry enterprise when classic efficiency tools begin to exhaust themselves.

In order to stimulate the automation of food production processes, including the use of robots and other elements of modular platforms, the Ministry of Industry and Trade of the Russian Federation in 2018 supported the acquisition of, for example, food processing equipment as part of the following measures, (Table 1):

Table 1. Measures of the Ministry of Industry and Trade of the Russian Federation aimed at supporting the acquisition of food equipment

\begin{tabular}{|l|l|c|}
\hline No. & Measure & $\begin{array}{c}\text { Decree of the Government of the } \\
\text { Russian Federation (date, No.) }\end{array}$ \\
\hline 1 & Purchase with a discount of at least 15\% of the price & May 10, 2017 No. 547 \\
\hline 2 & Acquisition of loans at preferential interest rates & February 17, 2018 No. 163 \\
\hline 3 & $\begin{array}{l}\text { Purchase pilot batches of production means with } \\
\text { preferential conditions }\end{array}$ & May 6, 2017 No. 634 \\
\hline
\end{tabular}

In the food and processing industry industrial robots, for example, are used to cut carcasses. Since about 2015 there are almost completely robotic systems for cutting and deboning the middle cut. Nevertheless, separate operations on the carcass cutting conveyor and in the boning workshop still need to be performed manually [22].

Robots are used on slaughter and cutting lines. They pre-scan the carcasses with a laser, pump out blood, saw them and cut them into half carcasses. Robotics determines the categorization of input raw materials by scanning in automatic mode (the thickness of the fat and the proportion of lean meat), which eliminates the influence of the human factor and reduces the technological time for accepting pigs.

Robotics is used on the packaging lines of finished products which eliminates human work at low temperatures and maximize the sanitary and hygienic quality of the finished product, (Table 2).

Table 2. Examples of robotics implementations in the food and processing industry

\begin{tabular}{|l|l|l|}
\hline No. & $\begin{array}{l}\text { Company and its } \\
\text { location }\end{array}$ & $\begin{array}{l}\text { Contents of the implementation of a robotics project in } \\
\text { production }\end{array}$ \\
\hline 1 & $\begin{array}{l}\text { Scott Technology, } \\
\text { New Zealand. }\end{array}$ & $\begin{array}{l}\text { The company is developing robots for processing cow and pork } \\
\text { carcasses; tests of machines for cutting sheep carcasses are } \\
\text { planned. The industrial robots developed by the New Zealand } \\
\text { company are capable of cutting 600 carcasses per hour. To monitor } \\
\text { a line of 12 devices only one operator is required. Working with } \\
\text { carcasses robots use computed tomography, and a 3D model is } \\
\text { generated based on the data obtained. Then the system carries out } \\
\text { cutting with a rotary knife. A sorting robot distributes products into } \\
\text { individual conveyor belts, weighs and packs, turning them into } \\
\text { finished products. The accuracy of the line is still 90\% (we are } \\
\text { talking about the accuracy of cuts and packaging). }\end{array}$ \\
\hline 2 & $\begin{array}{l}\text { Agropromkomplekt } \\
\text { atsia (SC } \\
\text { " AgroPromkomplek } \\
\text { tatsia "). }\end{array}$ & $\begin{array}{l}\text { By May 2017 the enterprise had completely robotic the process of } \\
\text { product delivery from the deboning department to the processing } \\
\text { and packaging department. Robot-manipulators pick up boxes of } \\
\text { meat from the deboning conveyor which are transported via } \\
\text { conveyor belts to a warehouse where products are automatically } \\
\text { sorted and subsequently transported to personnel processing and } \\
\text { packaging lines at the request of personnel. Empty boxes after } \\
\text { automatic washing and processing are delivered by conveyor to the } \\
\text { automatic warehouse of clean containers. }\end{array}$ \\
\hline
\end{tabular}


Continuation of Table 2. Examples of robotics implementations in the food and processing industry

\begin{tabular}{|l|l|l|}
\hline 3 & $\begin{array}{l}\text { Miratorg, Belgorod } \\
\text { region, Koroch . }\end{array}$ & $\begin{array}{l}\text { It is considered a pioneer of robotics in the meat industry of } \\
\text { Russia. The slaughter plant is one of the most robotic in } \\
\text { Europe. Robots replace a person on the slaughter line. }\end{array}$ \\
\hline 4 & $\begin{array}{l}\text { SC Cherkizovo } \\
\text { in Kashira Moscow } \\
\text { Region has launched } \\
\text { a robotic plant for } \\
\text { the production of } \\
\text { raw sausage } 80 \text { tons } \\
\text { per day. }\end{array}$ & $\begin{array}{l}\text { The plant is divided into zones: acceptance and automatic } \\
\text { storage, mince cooking, fermentation and drying, packaging and } \\
\text { engineering. All processes are fully automated and standardized, } \\
\text { each process and equipment has a digital double. Using robotics } \\
\text { allowed to reduce the number of plant employees from 700 to } \\
150 \text { [23]. } \\
\text { The main tasks that the new plant should solve were : } \\
\text { - a direct chain of production of one type of product - raw smoked } \\
\text { sausages; } \\
\text {-reduction of the human factor in the production process and errors } \\
\text { associated with this factor - the minimum human presence in the } \\
\text { workplace; } \\
\text {-Reduction of various safety risks in production; } \\
\text {-Full integration of all business processes. } \\
\text { So far, five to seven recipes are being worked out at the launch } \\
\text { launch, then there will be much more of them. At the same time, the } \\
\text { robotic plant allows you to be flexible in formulations. The system } \\
\text { automatically adjusts to their change and the set size (caliber) of the } \\
\text { sausage; you can also change the type and parameters of the } \\
\text { package }\end{array}$ \\
\hline
\end{tabular}

According to the general director of Cherkizovo Sergei Mikhailov the plant is unique in its class, not only because it is one of the largest in Russia and Europe but also because it uses the latest technology, the vast experience of the Cherkizovo group is invested in it and in the field of information technology, and industry[24].

\section{Conclusions}

Summing up, we can highlight the indisputable advantages that, in particular, are provided by the implementation of such a project for the construction of a fully robotic mono-plant, which is a clear implementation of the Industry 4.0 approach:

-total automation removes the human factor; integrated process chain;

-key indicators of production online;

-management of quality throughout the process chain;

-reliability of information throughout the chain;

-fewer gaps between the plan and operations;

-reliable information for making decisions on production and sales;

-reference points integrated into the production process do not allow to depart from the planned parameters.

\section{References}

1. Y.A. Sukhodolov, Studies in Systems, Decision and Control, 169 (2019)

2. C.B. Frey, M.A. Osborne, Technological Forecasting and Social Change, 114 (2017)

3. J. Manyika, Harnessing automation for a future that works (2017)

4. E.I. Pavlova, A.V.Kozlov, Proceedings of the scientific conference with international participation. Peter the Great Saint Petersburg Polytechnic University, 513 (2017) 
5. I.M. Rukina, V.V. Filatov, V.N. Zhenzhebir, I.V. Polozhentseva, Economic convergence and technological foresight. Microeconomics, 2 (2018)

6. K. Schwab, The fourth industrial revolution. Foreign Affairs. December 12 (2015)

7. M. Ghobakhloo, Journal of Manufacturing Technology Management, 29 (2018)

8. K. Lee, F. Malerba, A. Primi, Journal of Economic Policy Reform (2020)

9. Y. Yin, K.E. Stecke, D. Li., International Journal of Production Research, 56 (2018)

10. G.R.K. Reddy, H. Singh, S.Hariharan, ARPN Journal of Engineering and Applied Sciences, 11 (2016)

11. S.S. Nosova, A.N.b Norkina, S.V.b Makar, I.V. Arakelova, A.M. Medvedeva, V.Z. Chaplyuk, The digital economy as a new paradigm for overcoming turbulence in the modern economy of Russia. Espacios, 39 (2018)

12. V. Dzobelova, A. Olisaeva, S. Yablochnikov, V. Akasheva, S. Gerasimov, IDIMT2020, Digitalized Economy, Society and Information Management, 28th Interdisciplinary Information Management Talks, Schriftenreihe Informatik 49 (2020)

13. M. Ragnedda , G.W. Muschert, The Digital Divide: The Internet and Social Inequality in International Perspective (Routledge Advances in Sociology) (2015)

14. Balashova E., Gromova E., IOP Conference Series: Materials Science and Engineering, 1st International Conference on Contemporary Research in Mechanical Engineering with Focus on Materials and Manufacturing, ICCRME (2018)

15. V.Dravitsa, A. Kurbatsky, Science and Innovation, 3 (2016)

16. Y.I.P. Lopez, A.V.T. Jayachandran, F.C. Diaz, N.C.B. Flores, IAC. 70, Space: The Power of the Past, the Promise of the Future (2019)

17. I. Kazmina, P.Lukyanov, N.Zhminko, I.Savchenko, G.Yusupova, E. Zatsarinnaya, Talent Development and Excellence, 12 (2020)

18. K.A. Gulin, V.S. Uskov, Economic and Social Changes: Facts, Trends, Forecast, 10 (2017)

19. N. Ventsel, Norwegian Journal of development of the International Science, 18(3) (2018)

20. N.V. Putilo, N.S. Volkova, N.V. Antonova., Advances in Intelligent Systems and Computing, 1100 (2020)

21. K.B. Bleutaeva, Modern Science, 1 (2019)

22. X.B. Tran, International academic Bulletin, 5 (37) (2019)

23. R.V. Okorokov, News of universities "Economics, Finance and Production Management". St. Petersburg, 109 (2016)

24. Vladislav Belyaev, Economics and Life, 27 (2018) 